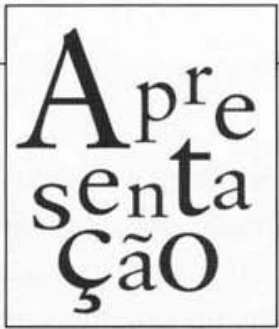

\title{
MEDIAÇÃO ORGANIZATIVA: O CAMPO DA PRODUÇÃO
}

$\mathrm{M}$ uito se fala sobre a linguagem dos meios de comunicação, sobre o ponto de vista que os meios escolhem para nos vender como o ponto de vista mais adequado, aquele que eles querem que seja o nosso ponto de vista sobre determinado fato.

Ocorre que nenhum fato existe em si. Ele existe sempre para nós. Ou seja, o fato existe sempre no relato que lhe dá a conhecer, o que não nega a existência da realidade concreta e objetiva.

Aproveitando a aproximação dos 500 anos da data convencionada para sacramentar a certidão de nascimento do Brasil ( 22 de abril), por exemplo, se tomarmos Cabral (Pedro Álvares, figura histórica), terras, ano de 1500, teremos três componentes da realidade objetiva, os quais se dão a conhecer ou pelo relato "Cabral descobriu o Brasil em 1500", ou por "Cabral chegou ao Brasil em 1500". Evidentemente, no primeiro caso - descobriu -, faz-se tábula rasa da cultura/história que aqui já existia (a indígena) e que, no decorrer dos séculos, viria a ser dizimada pelos portugueses (e se aqui usássemos a palavra invasores no lugar de portugueses?). No segundo caso - chegou -, está implícita a cultura/história que aqui existia, sem indicar, porém, qualquer tipo de relação com ela.

Eni Orlandi, comentando a expressão "Terra à Vista", que caracteriza a aproximação de navios aos portos, diz: "De que natureza seria [esse enunciado]: de júbilo, de surpresa, de alívio, de apreensão, de curiosidade? De todo modo, por significar porto, ele pode indicar, de um lado (daqueles que ancoram), a chegada (porto seguro) e, de outro (o dos que aqui estão), entrada (invasão). Promessa ou ameaça? Visitantes

A AUTORA
Maria Aparecida Baccega
Professora Livre-Docente do Departamento de Co-
municações e Artes da ECA-USP. Coordenadora do
curso de pós-graduação Gestão de Processos
Comunicacionais (lato sensu) e do Núcleo de Pes-
quisa de Telenovela (NPTN).


ou invasores? Terra a serviço de berço esplêndido? A ser pilhada? De quem, essa terra? ${ }^{\text {" }}$

Tratando das comemorações dos 500 anos, o escritor Kaká Jecupe, autor de $A$ terra dos mil povos, livro que conta a História do Brasil pela ótica daqueles que aqui se encontravam quando chegaram os portugueses, respondendo a perguntas sobre o significado da vinda dos portugueses, afirma que são 500 anos de desencontros, cuja "semente está numa sociedade que tem na sua estrutura de cultura a questão do ter e encontrou uma cultura aqui voltada para o ser (....) Hoje há um elemento a mais que são as indústrias farmacêuticas multinacionais, que estão praticando a biopirataria, roubando todo um conhecimento ancestral que os povos indígenas detêm a respeito de ervas medicinais" ${ }^{2}$. E, completa Jecupe, "para quem fundamenta a sua cultura no ter, a noção de progresso está em ver ao seu redor o acúmulo de bens materiais. A noção de progresso dos indígenas está em desenvolver a sua capacidade criativa, a sua expressão no mundo"3.

\section{PAUTA: O PONTO DE VISTA}

O mesmo evento da realidade objetiva configura-se em três diferentes fatos: os portugueses descobriram o Brasil, e sua implicação de desconsideração à cultura/história dos povos que aqui viviam; os portugueses chegaram ao Brasil, apontando para a dinâmica da vida dos povos que aqui habitavam e, finalmente, os portugueses desencontraram-se com o Brasil, mostrando duas culturas distintas que se confrontam.

Cada um desses relatos manifesta os condicionamentos sociopolítico-econômicos em que está imerso aquele que relata, o indivíduo/sujeito que assume um ou outro. Cada um deles manifesta um ponto de vista.

Falando sobre a construção do discurso da história, diz Schaff: "No seu trabalho, o historiador não parte dos fatos, mas dos materiais históricos, das fontes, no sentido mais extenso deste termo, com a ajuda dos quais constrói o que chamamos os fatos históricos. Constrói-os na medida em que seleciona os materiais disponíveis em função de um certo critério de valor, como na medida em que os articula, conferindolhes a forma de acontecimentos históricos. Assim, a despeito das aparências e das convicções correntes, os fatos históricos não são um ponto de partida, mas um fim, um resultado. Por conseguinte, não há nada de espantoso em que os mesmos materiais, semelhantes nisto a uma matéria prima, a uma substância bruta, sirvam para construções diferentes. E é aí que intervém toda a gama das manifestações do fator subjetivo: desde o saber efetivo do sujeito sobre a sociedade até as determinações sociais mais diversas" ${ }^{4}$. Se trocarmos historiador por comunicador, teremos aí uma síntese da construção dos fatos nos meios de comunicação: descobrir, chegar ou desencontrar constituem-se no ponto de chegada da seleção de ponto de vista realizada pelo comunicador.

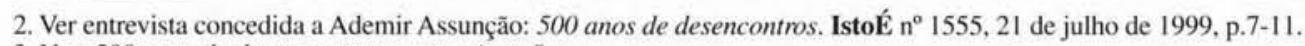

3. Ver: 500 anos de desencontros .... op. cit. p. 8.

4. SCHAFF, Adam. História e verdade. São Paulo: Martins Fontes, 1978. p. 307. 
Esse é um dos lados da construção da realidade nos/dos meios de comunicação. O outro lado é o lado ficcional, uma vez que o discurso da comunicação resulta da interação história/literatura; ficção/realidade ${ }^{5}$.

Resumindo, concordamos com Booth ${ }^{6}$ : "o autor [neste caso, o comunicador] pode imiscuir-se, mesmo que seja para manobrar diretamente as nossas emoções, desde que consiga convencer-nos de que as suas 'intrusões' são, pelo menos, tão cuidadosamente tecidas e tão pertinentes quanto as cenas que apresenta".

\section{PÚBLICO E PRIVADO}

A primeira grande escolha que se efetiva no âmbito dos meios de comunicação e que antecede a do ponto de vista que balizará o relato do fato, embora com ela interaja, é a que se refere à pauta.

Entre tantos acontecimentos que ocorrem na cidade, no país e no mundo, quais os que devem ser pautados, isto é, quais os que merecem aparecer no jornal, na revista, na televisão, fazendo compor o mundo como se apenas aqueles, os fatos escolhidos, fossem o mundo todo. Trata-se do processo metonímico - a parte pelo todo - que nos passa a convicção de que o mundo que existe é aquele, o escolhido, o selecionado, sem que tenhamos clareza de que a inclusão de um determinado fato significou a exclusão de um número infindável de outros que, por não chegarem aos meios de comunicação, não se tornarão públicos.

A mídia nunca é, portanto, apenas um testemunho da realidade, como se ouve com freqüência. Expressões como a antiga "Aconteceu virou manchete" ou "o fato real em tempo real", entre tantas outras, estão longe da realidade da mídia. Trazer um fato à boca de cena, escolhendo-o para divulgar, implica deslocar um problema do âmbito quase pessoal, dando-lhe características de problema da sociedade, o qual, a partir disso, ficará sob responsabilidade coletiva. "O que era mal-estar individual, vivido como íntimo ou privado, tende a se metamorfosear em assunto de conversação pública e, depois, em tema de colóquios e seminários de reflexão, em páginas de 'debate' dos jornais nacionais nas quais se enfrentam comentadores políticos e intelectuais midiáticos, abrindo por aí um verdadeiro mercado, economicamente rentável, para o qual afluem testemunhos e pesquisas, espontâneos ou encomendados."7

Os meios de comunicação se referenciam uns aos outros. Um fato noticiado em um jornal, por exemplo, certamente sairá também no rádio e na televisão. E nos demais jornais, com maior ou menor destaque, de acordo com a repercussão, de acordo com o nível

5. Ver BACCEGA, Maria Aparecida. Comunicação/Educação e transdisciplinaridade: os caminhos da linguagem. Comunicação \& Educação. São Paulo: CCA-ECA-USP/Moderna, n. 15, maio/ago. 1999. p. 7-14.

6. BOOTH, Wayne. A retórica da ficção. Lisboa: Arcádia, 1980. p. 220.

7. CHAMPAGNE, Patrick. A visão do Estado. In: BOURDIEU, Pierre et al. A miséria do mundo. 3.ed. Petrópolis: Vozes, 1999. p. 255. 
de aceitação pelo público, de acordo com o percentual de acerto com relação ao receptor: se efetivamente ele foi atingido, considerando-se seu perfil. Assim vai-se montando o agenda setting, ou seja, a temática que deverá empolgar a sociedade, que deverá ser alvo de discussões, a agenda pública.

A escolha dos fatos atende ainda ao aspecto da espetacularidade. Escolhem-se fatos que possam ser, eles próprios, verdadeiros espetáculos de imagens, de emoções construídas, de resgate de sentimentos às vezes ocultados pelo público e que encontram espaço, desse modo, para se expandirem.

Divulga-se o relato do fato. E o relato do fato traz o ponto de vista a partir do qual se pretende que ele seja compreendido: descobrir, chegar ou desencontrar, como já exemplificamos. Esse ponto de vista não se distinguirá muito do senso comum, estratégia que garante com possibilidade maior de êxito o sucesso da interpretação que a mídia pretende para aquele fato. Como diz Patrick Champagne, "ao mesmo tempo que o malestar é nomeado (por exemplo, 'o mal dos subúrbios' ou 'o mal-estar dos professores'), diz-se o que se deve pensar a esse respeito e tais interpretações impõem-se não somente àqueles que não se sentem envolvidos, mas também aos principais interessados; de fato, estes encontram aí um discurso legítimo sobre um mal-estar que já era sentido, de forma mais ou menos confusa, mas permanecia inexprimível porque considerado ilegítimo". ${ }^{8}$

Os fatos escolhidos para comporem a agenda temática, em conjunto com o ponto de vista sob o qual são veiculados, nem sempre são aqueles que possibilitariam o desenvolvimento da história por caminhos mais favoráveis à maioria.

É aí que reside o primeiro filtro, a primeira mediação: a mediação que se dá no âmbito da produção, a mediação que manifesta o modo pelo qual se organiza essa produção, seja o programa de rádio ou de televisão, seja a notícia, seja a publicidade. Trata-se da mediação organizativa, que leva em consideração seu público receptor, procurando selecionar o que há de mais conveniente tanto aos interesses da empresa a que pertence aquela mídia quanto ao perfil médio do público, levando ao senso comum, a uma repetição que procura travar o dinamismo da história. Talvez aqui expressões como "Rede Globo e você, tudo a ver" ou "de rabo preso com o leitor" possam ser melhor entendidas.

\section{SOBERANIA E MEIOS DE COMUNICAÇÃO}

Por esse caminho pode-se perceber que a proclamada independência, soberania ou autonomia do campo da recepção deve ser bastante relativizada. Se é verdade que o receptor (enunciatário/enunciador) mobiliza seu universo cultural para interpretar o que aparece nos meios de comunicação, seja de que gênero for, também é verdade que temos de levar em conta em nossas reflexões a mediação, o filtro que antecede o que

8. CHAMPAGNE, Patrick. A visão do Estado. op. cit. p. 255. Ver também BACCEGA, Maria Aparecida. Comunicação e tecnologia: educação e mercado de trabalho. Comunicação \& Educação. n. 2, São Paulo: CCA-ECA-USP/ Moderna, jan./abr. de 1995. p. 7-13. 
ele está vendo, ouvindo ou lendo: a mediação no campo da produção. Ele só interpretará aquilo que chegou ao seu conhecimento. E aquilo que chegou ao seu conhecimento foi escolhido, no âmbito da produção, levando em conta vários aspectos, sobretudo a orientação da empresa detentora daquela mídia.

As questões que se colocam no campo que produz essa mediação primeira são de extrema importância e muito pouco discutidas pela sociedade e até mesmo por aqueles que militam diretamente no campo da comunicação. Como lembra o jornalista Jânio de Freitas, falando da proposta de emenda constitucional sobre a propriedade dos meios de comunicação no Brasil, que tramita no Congresso Nacional, a abertura de $30 \%$ das empresas brasileiras de rádio, televisão e jornal ao capital estrangeiro trará enormes prejuízos políticos e sociais. "Mídia é informação, informação é matéria-prima da opinião pública, informação e opinião pública são a base da soberania de um país. Condicioná-las é também condicionar a soberania do país" ${ }^{10}$. A pauta não pode ferir os interesses da empresa e esses interesses nem sempre serão os nossos. Como ficaria, por exemplo, a discussão sobre a questão amazônica, de que ponto de vista ela seria tratada, numa hipotética contenda entre Brasil e EUA?, pergunta-se o jornalista. Afinal, a mídia associada não poderia definir sua posição "sem a influência do co-proprietário estrangeiro".

Ainda sobre a discussão dessa mediação organizativa, o campo do enunciador/ enunciatário, o pólo da emissão, da produção dos produtos veiculados pelos meios, o pólo que detém o poder de definir a pauta, ou seja, estabelecer quais os fatos que, na sua parcialidade, se revestirão do poder de representar a totalidade do mundo, tivemos, recentemente, acesso ao discurso de Pierre Bourdieu na reunião anual do Conselho Internacional do Museu da Televisão e do Rádio, uma associação das grandes empresas de mídia, com sede em Nova York.

A transformação de livros, filmes, jornais, revistas, programas de rádio e de televisão em mercadorias, na busca de lucros máximos a curto prazo, levou a uma homogeneização da produção dos meios de comunicação, que buscam repetir fórmulas que lhes garantam o sucesso imediato e, portanto, lucros certos.

Talvez a grande diferença entre os programas tenha passado a ser tão simplesmente o apuro do uso da tecnologia. (Poderia ser esse o caso dos programas Ratinho, do SBT e Linha Direta ${ }^{\prime \prime}$, da Globo). Bourdieu lançou um desafio ao auditório: desprezar o poder comercial, abrindo espaços para que haja uma efetiva diversificação da oferta cultural, na busca de obras universais, as quais, em seu nascedouro, estão sempre distantes das normas dos produtos comerciais.

Comentando a palestra de Bourdieu, Acessocom ${ }^{12}$ retoma o fato contado pelo sociólogo na ocasião e que "relata a forma pouco protocolar com que o pintor e escultor Michelangelo Buonarotti tratava seus clientes. Um deles era o papa Júlio II. Ao

10. FREITAS, Jânio de. Os riscos de socorro. Folha de S. Paulo. 24 de outubro de 1999. p. 6.

11. Ver, neste número de Comunicação \& Educação, BUCCI, Eugênio. Linha Direta com quem? p. 91.

12. Acessocom - Jornalismo especializado em comunicação. Publicação do Epcom (Instituto de Estudos e Pesquisas em Comunicação), 10 de novembro de 1999. www.acessocom.com.br 
posar para o artista, o sumo pontífice era obrigado a sentar-se rapidamente, antes que Michelangelo o fizesse. Ao desconhecer a posição ou influência do modelo, Michelangelo dava à sua obra e ao seu trabalho a independência necessária para um produto final qualificado".

Quando falamos em mediação no âmbito da produção estamos nos referindo também "aos processos organizativos dos meios de comunicação. É considerada a influência do contexto da produção - tanto se for concebido como um entorno profissional, uma organização específica, uma indústria, ou, mais em geral, como as relações sociais de poder na sociedade - sobre o que se produz"13. Por exemplo, a produção independente, $o$ free lance, hoje bem mais comum nos trabalhos da indústria cultural, acabaram por possibilitar inovações e variações ou essa possibilidade se apaga diante de outro fato avassalador: o crescimento dos impérios de comunicação, hoje em escala mundial, ditando um deverser, um fazer? Ou, como coloca James Curran, "é possível diferenciar entre contextos de produção que estimulam um crescimento da sociedade ou sua subordinação, que promovem a inovação estética ou o tradicionalismo, que realçam ou desmerecem a qualidade"14.

Essas considerações têm por objetivo nos remeter a discussões cada vez mais urgentes na sociedade brasileira e imprescindíveis para a construção da cidadania: como está, no Brasil, essa mediação organizativa. É aí que se institui o verdadeiro campo da educação que, hoje, é uma releitura do campo da comunicação.

\section{ARTIGOS NACIONAIS}

Discurso da propaganda e Diretrizes Curriculares é o artigo de Cláudia Lukianchuki que abre a seção. Alerta para que se diga "não à escola reprodutiva! Sim à escola que estimula a criatividade, a inventividade, a criticidade". Segundo a autora, para que a estética da sensibilidade, a política da igualdade e a ética da identidade sejam efetivas, o ensino tem de ser inter e transdisciplinar. Partindo de uma discussão sobre a linguagem como formadora do pensamento e do conhecimento, Lukianchuki analisa o discurso da publicidade. Fala da persuasão, dos estereótipos, da manipulação dos valores e ideais humanos contidos nesse e em outros discursos e como (re)conhecer todas essas marcas. "Ler-produzir um texto é reconstruí-lo no campo das relações que se instituem entre ele e o ser humano. É fazer dessa relação uma produção social a partir da qual se possa refletir/refratar o universo no qual está inserida", diz a autora. E uma dessas relações é a mediação organizativa, que se situa nas condições de produção desses discursos.

As linguagens institucionais não-escolares, principalmente as dos meios de comunicação, estão presentes na escola. Fundamental é o diálogo que se deve manter entre essas linguagens. Afinal, "os modos de aprender/apreender estão se alte-

13. CURRAN, James et al. Estudios culturales y comunicación. Análisis, producción y consumo cultural de las políticas de identidad y el posmodernismo (Estudos culturais e comunicação. Análise, produção e consumo cultural das políticas de identidade e o pós-modernismo). Barcelona: Paidós, 1998. p. 258.

14. CURRAN, James et al. Estudios... p. 258. 
rando. Por exemplo, as noções de tempo e espaço ganharam outras dinâmicas, (....) tudo ficou perto, o outro lado do mundo é logo ali, é possível estar em Tóquio, Paris e Buenos Aires nos quinze minutos do telejornal", diz Adílson Odair Citelli, em Meios de comunicação e práticas escolares. Para o autor, "se a escola deve melhorar seus jogos interlocutivos com os meios, precisa fazê-lo não só para estar em sintonia modernizante com o novo, com o sedutor, mas também para tensionar e desestabilizar, quando necessário, um tipo de mensagem da qual não se exclui o elemento de espetáculo e maniupulação". Para isso estamos buscando colaborar.

Roseli Fígaro, em Estudo de recepção para a crítica da comunicação, traz sua colaboração apontando a necessidade de se analisar os produtos dos meios de comunicação levando-se em conta a recepção. Seu primeiro alerta vem no sentido de mostrar a postura ambígua daqueles que, sobretudo alunos, se detêm a criticar a manipulação dos meios de comunicação e, à primeira oportunidade de realizar um trabalho nesse campo, "abandonam completamente a postura crítica que adotavam e passam então a incorporar a postura hegemônica na edição de suas peças publicitárias, de seus filmes, enfim de todos os produtos culturais que sua profissão lhes permitirá executar". No campo da mediação organizativa, diz a autora que o poder das grandes empresas "tem de ser questionado via democratização da posse dos meios de comunicação, via participação das comunidades na elaboração das políticas e da legislação que regulam a concessão e a posse dos meios de comunicação, não só discutindo sobre o direito das comunidades ao espaço da radiodifusão, mas sobretudo questionando qual é o compromisso legal das empresas com a sociedade civil ao utilizarem um serviço público".

Segundo os historiadores, o século XX foi o século mais violento da história da humanidade. Como tem atuado a mídia diante dessa realidade? $\mathrm{E}$ o que se pode fazer na escola objetivando possibilitar a formação de um cidadão mais crítico? É o que discute Marta Gouveia de Oliveira Rovai, em Imagens da guerra: do horror à sedução. Segundo a autora, a televisão "tem um papel cada vez maior na cobertura dos conflitos, trazendo para dentro dos lares (e indiretamente das escolas, pois os alunos trazem para a sala de aula) as informações e as imagens observadas e recebidas, na maioria das vezes, como frutos da imparcialidade e da neutralidade da câmera que as captou". Oportuna, portanto, a discussão dos temas tratados em mediação organizativa: como se constrói o ponto de vista e como se decide uma pauta, para que os alunos possam perceber as seleções prévias, a não neutralidade dos noticiários, sejam os da televisão, do rádio ou dos jornais. "Mais do que nossa participação virtual num jogo de guerra, precisamos identificar sujeitos e intenções, e compreender o tecido de relações nas quais estão inseridos, sendo informados e formados para também interferir e formar' o mundo."

Ética e meios de comunicação, de Maria Ignês Carlos Magno, relata a experiência da autora com alunos das oitavas séries. Um dos temas foi a violência, que "faz parte da vida de cada um, não apenas dos telejornais", que "está presente nas escolas centrais e periféricas, e nos anúncios que convidam, entre um bloco e outro dos telejornais, o telespectador a assistir ao filme da noite". 
Terra Nostra, novela de Benedito Rui Barbosa, ainda não estava no ar quando Maria Lourdes Motter trouxe sua colaboração. Telenovela e educação: um processo interativo é o artigo que vai mostrando de que modo se pode trazer para discussão um produto cultural tão importante quanto a telenovela. Ela fala do desprezo e do preconceito que vigem com relação à telenovela, considerada produto menor. "Se admitíssemos que elas não têm nada de bom a oferecer, mais justificado seria trabalhar com o gênero. Pois é nossa a responsabilidade de refletir sobre o que constitui o cotidiano de nossos educandos, dos nossos filhos, bem como analisar o que se passa nessa relação receptiva. A telenovela está entrando, queiramos ou não, na nossa cultura, no nosso dia-a-dia, esse é mais um traço a compor a realidade. Ao nos recusarmos a olhar de frente para a telenovela, automaticamente estamos fechando os olhos para um aspecto da realidade. Começamos errando por aí."

\section{ARTIGOS INTERNACIONAIS}

Giovanni Bechelloni, em Audiência: uma abordagem sociológica da comunicação, inicia a seção. Ele vai tratar das questões de comunicação na Itália, abordando temas que muitas vezes estão bastante próximos de nossa realidade. Ressalta que os receptores "são indivíduos-pessoas dotados de livre-arbítrio, capazes de compreender e de querer, depositários de direitos e de deveres, capazes, portanto, de fazer escolhas e de cotidianamente ser obrigados a fazer escolhas, mesmo dentro dos limites consentidos, dos horizontes e das condições de vida de cada um". Aqui, segundo o autor, está "a face oculta da mídia", a qual precisa ser respeitada, "para produzir melhor, com profissionalismo mais elevado e com maior ética, as numerosas mensagens que ela produz cotidianamente, tendo-se consciência de que os seus produtos não são inócuos, ou seja, de que eles têm sentido e contribuem para dar sentido às vidas".

Educação para os meios na Itália, artigo de Chiara Salvadori, aborda a temática comunicação/educação, trazendo contribuições importantes. Ela trata da formação tanto de alunos quanto de professores, mostrando, também, qual a contribuição da academia nesse campo. Na verdade, a autora considera que "é importante que teoria e prática, tecnologia e cultura, ensinamento e aprendizado, trabalho escolar e extraescolar, nível local, nacional e global, ofertas midiáticas e atividades educativas sejam consideradas separadamente, mas como "sistemas complexos".

O teatro, nas suas mais diversas manifestações, continua a ser motivo de encantamento para o público infantil. Como se dá esse processo de recepção? É o que discute Mafra Gagliardi, em Recepção infantil da obra teatral. A autora apresenta os resultados de uma pesquisa realizada nos anos de 97-98, envolvendo 15 centros de teatro para juventude, 25 espetáculos e cerca de 1.700 espectadores de 3 a 14 anos. "Da totalidade das respostas das crianças fica confirmado que o espetáculo teatral opera sobre elas um forte envolvimento emocional conjunto", diz a autora. Como isso se dá é o que revela o artigo. 


\section{ENTREVISTA}

Lauro César Muniz é um dos maiores dramaturgos da televisão brasileira. E, por que não dizer, um cidadão que tem sabido colocar sua vida a serviço da construção da cidadania de todos os brasileiros. Seu último trabalho, Chiquinha Gonzaga, foi sucesso de público e de crítica. É ele o entrevistado deste número. Vale a pena ler Uma nova linguagem para a telenovela, entrevista de Roseli Fígaro.

\section{CRÍTICA}

Linha Direta com quem? é o artigo do jornalista Eugênio Bucci. Ele analisa as várias encarnações desse programa, hoje levado ao ar por Marcelo Rezende, na Rede Globo. O autor alerta para a delação, constituída em espinha dorsal do programa, discutindo-a como uma das faces de um Estado policial, totalitário.

\section{DEPOIMENTO}

João Antônio Batista, radialista da Rádio Cultura, fala de seus Dez anos nas ondas do rádio, percorrendo suas experiências desde a fase de estagiário. Entre os vários programas, destaque para Língua brasileira, depois denominado Nossa Língua Portuguesa, iniciado no rádio e hoje de grande êxito também na televisão.

\section{EXPERIÊNCIA}

A revista traz dois relatos de experiências de sala de aula: o primeiro, de Sibéria Regina de Carvalho, da Rede Estadual de Ensino, Escola Ilga Pusplatais, de São José dos Campos e o segundo, de Izilda Bueno Barrios Campanhão, professora do Ensino Fundamental da Rede Estadual, Escola Bento Carlos Botelho do Amaral, em Guariba.

Em Poesia e meio ambiente, Sibéria apresenta projeto desenvolvido com seus alunos, baseado na interdisciplinaridade, ao final do qual se mesclam poesia e respeito ao meio ambiente como conquistas definitivas dos alunos.

Jornal na escola: conhecimento e auto-estima, de Izilda, apresenta projeto desenvolvido com jornais, revistas e textos informativos, objetivando a construção de um jornal, que circula em toda a escola, com grande êxito.

\section{POESIA}

O Brasil perdeu João Cabral de Melo Neto. Tudo que se dissesse seria pouco. Registre-se a homenagem da nossa revista. 


\section{SERVIÇOS}

Estamos publicando o Manifesto 2000. Por uma cultura de paz e não violência, formulado por personalidades premiadas com o Nobel da Paz. Movem-nos pelo menos duas finalidades: ratificar o objetivo da nossa revista, na busca de uma sociedade de paz e igualdade entre os homens e possibilitar a cada escola, cada professor, cada aluno, cada pai, cada cidadão que tenha acesso a ele, que se comprometa com ele e o assine.

Ainda em serviços o artigo de Maria Aparecida Silva Bento, Trabalho e desigualdade, em que a autora nos permite conhecer os cursos de capacitação sindical, para a cidadania, interação pluriétnica, entre outros, oferecidos pelo Centro de Estudos das Relações de Trabalho e Desigualdades (CEERT).

\section{VIDEOGRAFIA}

Traz neste número três documentários que Maria Ignês Carlos Magno escolheu e comentou para tratar do tema Brasil: 500 anos de que história?

\section{BIBLIOGRAFIA}

Seguimos com às bibliografias sobre comunicação e educação e sobre telenovela; e inauguramos endereços úteis na Internet.

Resumo: Através do discurso da História - o de 500 anos de descoberta do/chegada ao Brasil - a autora discute a questão do ponto de vista presente em um relato, seja o discurso da história ou os relatos da mídia. Ressalta que é já na elaboração da pauta dos temas a serem veiculados pelos meios de comunicação que se seleciona, dando evidência a um fato, apagando-se outros, tirando um assunto do âmbito pessoal para torná-lo um tema de amplitude social. Destaca as principais características da mediação organizativa, a que se dá no âmbito da produção, entre as quais as relações de poder na sociedade, os interesses da empresa - a busca do lucro -, a soberania nacional. O conhecimento desses aspectos, afirma a autora, devem nos fazer relativizar a tão proclamada independência do sujeito/receptor, levando-nos à compreensão dos fatores limitadores que incidem sobre suas escolhas.

Palavras-chave: mediação organizativa, campo da produção, pauta, ponto de vista, História, meios de comunicação
Abstract: Through History discourse - that of the 500 years of the discovery of/arrival in Brazil - the author discusses the matter from the current point of view in a report, whether this be a discourse of history or in media reports. She emphasizes that it is when the agenda of the themes to be covered are discussed that the matter is selected. In this process one fact highlighted, while others are erased. A subject is removed from the personal realms and made it one of social amplitude. She stresses the main characteristics of organization mediation, the one that takes place in the realm of production, among which power relations in society, company interests - the search for financial gain -, and national sovereignty. Knowing these factors, claims the author, must make us consider the so proclaimed subject/receptor independence as relative, leading us to understanding the limiting factors that befall on our choices.

Key words: organization mediation, production field, agenda, point of view, History, means of communication 